\title{
ROLE OF CENTRAL GHRELIN IN MAINTAINING ENERGY HOMEOSTASIS
}

\author{
$\mathscr{B}_{y}$ \\ Gehan A. Elwakeel, MD., Vivian B. Abdou \\ and Gehan Ahmed Shaker, MD.

\begin{abstract}
From
of pharmacology, Lecturer of Physiology.
\end{abstract} \\ Lecturer of Physiology, assistant professor
}

\begin{abstract}
Background

In the past few years, much progress has been made in the understanding of how people maintain body weight and how energy homeostasis is affected. Many homeostastic processes including appetite and food intake are controlled by neuroendocrine circuits involving the C.N.S. Mean while the C.N.S. may directly regulates adipocyte metabolism.

\section{Objective}

In this work we aim to show and prove that central ghrelin in physiological not pharmacological dose plays an important role in maintenance of energy homeostasis.

\section{Methods}

2 sets of experiments were carried out to investigate both the acute and chronic effects of intrace-
\end{abstract}

rebroventricular Ghrelin on energy homestasis and adipocyte metabolism. Each set of experiment include 3 groups, each group consists of 8 rats :

group A (control group) : Were injected daily with saline in a dose of 5 ML saline, group B (physiological dose group) Were injected daily with ghrelin in a dose of $2.5 \mathrm{nmol}$, group C (pharmacological dose group): Were injected daily with ghrelin in a dose of 4 nmole. For all groups, samples were collected both in the fasting and in the postprandial states.

In the acute study, the rats were sacrificed after 24 hours and in the chronic study, the rats were sacrificed after 6 days. In all chronic groups beside the blood samples: the epididymal white adipose tissue was dissected for estimation of triglyMANSOURA MEDICAL JOURNAL 
ceride content, weight measurement and histological analysis, mRNA expression of the lipoprotein lipase enzyme, the carnitine palymitoyl transferase enzyme, UCP2 and the UCP1

Results

Group B (physiological dose) in the acute study: plasma glucose, free fatty acids and triglycerides showed significant increased as compared with the control group (group A) while in the postprandial it showed significant decrease in all these parameters as compared with the control group and in the pharmacological dose showed significant increase in fasting plasma glucose, plasma free fatty acids and insignificant change in triglyceride level as compared with the control group.

However in the chronic study the pharmacological doses showed insignificant change in plasma glucose while significant decrease in plasma free fatty acids and triglyceride as compared with the control group. The physiological dose by chronic study showed significant increase in plasma glucose and non significant change in plasma free fatty acids and triglycerides as compared with the control group. Also in the pharmacological group (gpC) showed an increase in the body weight an increase in epididymal WAT tissue weight gain and triglyceride concentration in WAT tissue, Also gpC showed significant increase in mRNA level of lipoprotein lipase (increase by $200 \%$ of control), significant decrease in mRNA level of carnitine palmitoyl transferse ? (decrease by $60 \%$ of control), significant decrease in mRNA level of UCP1 (decrease by $60 \%$ of control) and significant increase in mRNA level of UCP2 (increase by $50 \%$ of control).

\section{Conclusion}

Central ghrelin in its physiological concentration has a subtle effect which enables it to maintain constant fat stores. Central ghrelin in the pharmacological dose enhances triglyceride storage and decrease level of energy expenditure thus it causes a +ve energy balance and also it may worsen a diabetic state.

Key words:

Central ghrelin - Energy homeostasis - UCPs

\section{INTRODUCTION}

In energetic terms, fat storage oc- 
curs when energy intake exceeds energy expenditure. At the level of white adipose tissue (WAT) an increase in fat mass arises from two distinct cellular processes; an increase in fat mass and/or an increase in adipocyte size as a result of increased storage of lipid.

The storage of lipid in mature adipocyte is the net result of four distinct processes: The uptake of metabolic substrate, denovo synthesis of lipids within the adipocyte (lipogenesis), the breakdown and mobilization of stored lipid (lipolysis) and lipid export (1 and 2).

The number of adipocytes and their lipid storage activity are tightly regulated so that individual body weight and fat distribution may remain remarkably constant, even over periods of many years. This regulation of fat homeostasis is achieved by complex array of central and peripheral determinants. Uncoupling proteins (UCPs) are located on the inner mitochondrial membrane and play an important role as free fatty acid anion transporters to allow proton re-entry into the mitochondrial matrix (3).
UCPs includes many types. In contrary to UCP1, the function of UCP2 remains unclear. However, there is the possibility that UCP2 may participate in basal thermogenesis because several genetic studies have indicated genetic linkage of UCP2 locus to the resting metabolic rate ( 4 and 5 ).

Ghrelin is a neuropeptide hormone. That was initially identified as an endogenous ligand for the orphan GH-secretaguogue receptor GHisR1a (6). Despite initial evidence of ghrelin production in the hypothalamus in particular the ventral arcuate nuclei (6 and 7). Hypothalamic expression of ghrelin mRNA is very low . A discrete group of ghrelin positive neurons has been identified adjacent to the $3^{\text {rd }}$ ventricle between the dorsomedial, VMH, PVN and arcuate nuclei (8).

These neurons make synaptic contact with neuropeptide y, AgRP, proopiopmelancortin and corticotropin releasing hormone containing neurons, where they enhance the activity of orexigenic circuits (8). However the extent and functional relevance of brain derived ghrelin

MANSOURA MEDICAL JOURNAL 
still needs to be clarified.

Objective: We test in this work that ghrelin injected intracerebroventricular in a dose close to its normal physiological level plays an important role in maintaining energy homeostasis. While ghrelin injected intracerbebroventricular in a pharmacological dose approximating the increment in centrally derived ghrelin which occur under certain conditions promotes a positive energy balance. This may be a candidate for a benefit of the pharmacological dose of ghrelin acting centrally in some debilitating diseases such as cachexia and anorexia nervosa. Also to highlights the physiological relevance of centrally derived ghrelin to protect against periods of food scarcity by building energy reserves predominantly in the form of fat. And possible benefit of ghrelin antagonism in controlling obesity and types 2 diabetes mellitus.

\section{MATERIALS AND METHODS}

- 2 sets of experiments were carried out: One to investigate the acute effects of intracerebro ventricular (icv) Ghrelin on energy homeostasis and adipo- cyte metabolism

- Another experiment to investigate the effect of chronic icv ghrelin on energy homeostasis and adipocytes metabolism.

Investigation of acute effects of icv ghrelin:

- Rats weighing from 300 - 400 divided into 3 groups. Each group consists of 8 rats:

Group $A$ (control group) : rats were sacrificed 24 hours after single injection of $5 \mathrm{ML}$ saline.

Group $B$ : 8 rats were sacrificed 24 hours after a single injection of $2.5 \mathrm{nmol}$ ghrelin i.e. physiological dose (10).

Group $C$ : 8 rats were scarified 24 hours after a single injection of $M L$ of $4 \mathrm{nmol}$ of ghrelin i.e. pharmacological dose (9).

For all groups, samples were collected both in the fasting and the postprandial states.

For each group, the animals were killed by decapitation.

Blood samples were collected.

Serum was separated and frozen immediately at $20^{\circ} \mathrm{c}$. and then assessed for:

1. Level of serum glucose.

2. Level of serum triglycerides. 
Gehan A. Elwakeel, MD et al ....

3. Level of serum fatty acids.

Determination of free fatty acids

- The principle based on the calorimetric method already described for chloroform solution of fatty acids reagents .

\section{Glucose estimation}

The concentration of glucose in serum was determined by an enzymatic method using glucose enzymatic IGt.

Triglyceride estimation :

Serum triacylglycerols was determined enzymaticaly.

Assessment of chronic effects of I.C.V Ghrelin

The study includes 3 groups of 8 rats weighing $300-400 \mathrm{gm}$.

Group A (control group)

The rats were injected daily with $5 \mathrm{ML}$ of saline icv for 6 days..

Group B

The rats were injected daily icv with $2.5 \mathrm{nmol}$ of ghrelin for 6 days (physiological) dose

Group C

The rats were injected daily icv with $4 \mathrm{nmol}$ (pharmacological dose) of ghrelin for 6 days

The weight of the rats were measured before the ghrelin injection and after 6 days of the injection.

\section{Surgery}

All animals were anesthetized with i.p. pentobarbital $(50 \mathrm{mg} / \mathrm{kg}$ b.w.) and a 20-gauge stainless guide cannula was positioned stereotaxically above a lateral cerebral ventricle at the following corrdinates: $1.7 \mathrm{~mm}$ lateral to the midline. $0.4 \mathrm{~mm}$ posterior to the bregma, $3.0 \mathrm{~mm}$ from the cranial theca. Rats were given 7 - 10 days to recover from surgery as judged by recovery of preoperative body weight.

\section{Procedure}

After recovery of animals. The animals were anesthetized with urethane (1.2 g/kg b.w. i.p.) and mounted in a stereotaxic instrument (Stoelting). The level of anesthesia was kept constant as evaluated by skeletal muscle relaxation, eye and palpebral responses to stimuli. The skull was exposed and a microdialyssi probe was inserted at following coordinates: $1.2 \mathrm{~mm}$ posterior to bregma. $0.6 \mathrm{~mm}$ lateral to midline. $8.5 \mathrm{~mm}$ from cortical surface.

\author{
Assessment \\ Includes: \\ 1. Dissection of epididymal WAT in \\ which is used for
}

MANSOURA MEDICAL JOURNAL 
1.1 Estimation of triglycerides content of adipose tissues.

1.2 Histological analysis.

1.3 Measurement of epididymal WAT weight .

1.1 Estimation of triglyceride content in adipose tissues

The method was modified slightly from that described by Qian etal., (11) : Briefly $100 \mathrm{mg}$ of WAT was homogenized in $2 \mathrm{ml}$ af a solution containing $150 \mathrm{mM} / 1 \mathrm{Nacl}, 0.1 \%$ triton $\mathrm{x}, 100$ and 0.1 of triton $\mathrm{X}-100$ and $10 \mathrm{mM} / 1$ Tris, $\mathrm{pH} 8$ and $50 \mathrm{C}$ using a polytron homogerizer for $1 \mathrm{~min}$.

The triglyceride content of this $\mathrm{ML}$ solution was determined using commercially available kit (Wako, Tokyo, Japan).

1.2 Histological analysis :

WAT samples were fixed with $10 \%$ formalin and embedded in paraffin. Sections were cut at $20 \mathrm{Mm}$ and stained with hematoxylin and eosin.

The histology of white adipoctes were used by the analysis system [Olympus, Tokyo, Japan] :

1. The number of adipocytes was Vol. 44, No. 1 \& 2 Jan. \& April, 2015 counted in 5 appropriate limited areas. (WAT; 25 * 10-3 mn2) of each stained specimen HEstained sections were analyzed with an image analysis system (Olympus, Tokyo, Japan).

2. Measurement of histological quantifications were performed on a computerized microscope system (BX-50, Olympus, Tokyo, Japn). The picture displayed on the monitor (Tx - MgT5s - T, Matsusita Electric Industry, Osaka, Japan) was analyzed by specialized soft ware (Studiolite, Apple store, Tocyo, Japan).

1.3 Determination of the weight of epididymal fat.

2. Blood samples were collected after decapitation for measurement of serum glucose and FFA and triglyceride levels.

3. The weight of the Rats were measured before the ghrelin injection and after 6 days of the injection.

4. Real time quantitative reverse transcription polymerase chain reaction :

3 studies were designed to measure mRNA expression of enzymes involved in lipid metabalim and thermogenesis related processes follow- 
ing icv injection of 4 nmole ghrelin concentration was determined by for 6 days and icv injection of 2 spectrophotometry. cDNA templates nmole ghrelin for 6 days and icv injection of $5 \mathrm{ML}$ of saline for 6 days. These experiments includes assessment of:

4.1 mRNA expression of the fat storage enzyme lipoprotein lipase.

4.2 mRNA expression of the enzyme involved in the rate limiting step in fat oxidation : carnitine palmitoyl transfersase $1 \alpha$.

4.3 mRNA expression of WAT UCP2 mRNA.

4.4 mRNA expression of WAT UCP1 mRNA.

Quantitative RT-PCR, Animals were killed by decapitation in the fed state (1-4 hours after morning feeding) and various tissues were sampled, freeze-clamped, ad stored at $80^{\circ} \mathrm{C}$ for subsequent measurement of mRNA LPL, CPT-1? and UCP2 by real-time quantitative PCR (Lightcycler; Roche Diagnostics).

Total RNA was extracted from frozen tissue samples usingTrizol Reagent (Invitrogen Corp). RNA integrity was assessed by performing a $1 \%$ agarose gel electrophoresis in $1 *$. Tris-borate-EDTA, and its for RT-PCR were obtained using 2.5 ?g of total RNA. Reverse transcription reaction was performed with random hexamers (Microsynth), dNTPs, RNAse inhibitor, Rnasin (Catalys; Promega), and the M-MLV-RT enzyme kit (Invitrogen Corp).

Amplification of cDNAs was performed with the SYBR Green I DNA master kit (Roche Diagnostics), according to the light cycler standard protocol, using around $70 \mathrm{ng}$ template cDNA. All primers were used at a final concentration of 0.5 ?M. After each run, a relative quantification of the amplified PCR product in the different samples was performed. This was based on the relative comparison of the PCR products during the log-linear phase of the amplification process. A standard curve was used to obtain the relative concentration of the target gene, and the results were corrected according to the concentration of cyclophilin B, or RPS29, used as housekeeping genes. The results are expressed as percent of controls, setting the mean of the control group at $100 \%$ and then 
ROLE OF CENTRAL GHRELIN IN MAINTAINING etc..

calculating each individual value of the 3 groups of animals studies.

Primer sequences

LPL forward 5'TCTCCTGATGATGCGGATTT-3

Reverse 5

CAACATGCCCATCTGGTTTC-3

CPT1 $\alpha$ forward 5 GGATGGCATGTGGGTAAAAG-3 Reverse 5'-

TACTGACACAGGCAGCCAAA-3

UCP1 $1 \alpha$ forward 5 -

GCCTCTACGATACGGTCCAA-3

Reverse 5`-

TGCATTCTGACCTTCACCAC-3

UCP2 forward 5 -

TCTGGGATACCGCCAAGGT-3

Reverse 5`-

TTGTAGAGGCTGCGTGGA-3

\section{Statistical Analysis}

Values were expressed in the form of (+/-) SD which are done by using excel program for figures and SPSS (SPSS, Sigma Plot Software, Inc, Chicago, IL) program statistical package for social science version 16. To test the normality of data distribution K-S (KolmogorovoVol. 44, No. 1 \& 2 Jan. \& April, 2015
Smirnov) test was done only significant data revealed to be nonparametric.

N.B: all tested data revealed to be parametric.

The description of data was done in the form of mean (+/-) SD for quantitative data and frequency \& proportion for qualitative data. The analysis of the data was done to test statistical significant difference between groups. For quantitative data student t- test was used to compare between groups. One way ANOVA was used to compare more than two groups. Paired sample t-test to compare one group at different times. To test the association between variables correlation co-efficiency test was done.

N.B: $P$ is significant if lower than 0.05 at confidence interval 95\%. The level of significance as the follow: $\mathrm{P}>$ 0.05 non-significant, $\mathrm{P}<0.05$ significant, $\quad P<0.01$ highly significant, $P<0.001$ very highly significant

\section{RESULTS}

P1 : gpB as compared with gp. A $\mathrm{P} 2$ : gpB as compared with gp C 
P3 : gpC as compared with gp A

Plasma glucose level in the fasting state following injection of ghrelin for one day in a dose of $2.5 \mathrm{nmol}$ and $4 \mathrm{nmol}$ as compared with control

Plasma glucose level in the postprandial state following injection of ghrelin for one day in a dose of $2.5 \mathrm{nmol}$ and $4 \mathrm{nmol}$ as compared with control

Plasma free fatty acid level in the fasting state following injection of ghrelin for one day in a dose of $2.5 \mathrm{nmol}$ and $4 \mathrm{nmol}$ as compared with control

Plasma free fatty acid level in the Postprandial state following injection of ghrelin for one day in a dose of $2.5 \mathrm{nmol}$ and $4 \mathrm{nmol}$ as compared with control

Triglycerides plasma level in the fasting state following injection of ghrelin for one day in a dose of $2.5 \mathrm{nmol}$ and $4 \mathrm{nmol}$ as compared with control

Triglycerides plasma level in the Postprandial state following injection of ghrelin for one day in a dose of $2.5 \mathrm{nmol} 4 \mathrm{nmol}$ as

compared with control

plasma glucose level following injection of ghrelin for 6 days in a dose of $2.5 \mathrm{nmol}$ and in $4 \mathrm{nmol}$ as compared with control

Plasma free fatty acids following injection of ghrelin for 6 days in a dose of $2.5 \mathrm{nmol}$ and $4 \mathrm{nmol}$ as compared with control

Plasma triglycerides following injection of ghrelin for 6 days in a dose of $2.5 \mathrm{nmol}$ and $4 \mathrm{nmol}$ as compared with control

Body weight following injection of ghrelin for 6 days in a dose of $2.5 \mathrm{nmol}$ and $4 \mathrm{nmol}$ as compared with control

Epididymal WAT tissue weight gain following injection of ghrelin for 6 days in a dose of $2.5 \mathrm{nmol}$ and $4 \mathrm{nmol}$ as compared with control

Triglycerides concentration in epididymal WAt tissue following injection of ghrelin for 6 days in a dose of $2.5 \mathrm{nmol}$ and $4 \mathrm{nmol}$ as compared with control

MANSOURA MEDICAL JOURNAL 
$\%$ control of UCP1 in epididymal WAt tissue following injection of ghrelin for 6 days in a dose of $2.5 \mathrm{nmol}$ and $4 \mathrm{nmol}$ as compared with control

\% control of UCP2 in epididymal WAt tissue following injection of ghrelin for 6 days in a dose of $2.5 \mathrm{nmol}$ and $4 \mathrm{nmol}$ as compared with control

$\%$ control of mRNA level of lipoprotein lipase enzyme in epididymal WAt tissue following injection of ghrelin for 6 days in a dose of $2.5 \mathrm{nmol}$ and $4 \mathrm{nmol}$ as compared with control

$\%$ control of mRNA level of carnitine palmitoyl tranferase $1 \alpha$ in epididymal WAt tissue following injection of ghrelin for 6 days in a dose of $2.5 \mathrm{nmol}$ and $4 \mathrm{nmol}$ as compared with control

Table (1) : Effect of acute injection of ghrelin on plasma glucose, free fatty acids and triglycerides levels in the fasting and postprandial states.

\begin{tabular}{|c|c|c|c|c|c|c|}
\hline & \multicolumn{2}{|c|}{$\begin{array}{c}\text { Plasma glucose mg/d } \\
\text { Mean } \pm S . D\end{array}$} & \multicolumn{2}{c|}{$\begin{array}{c}\text { Frea fatty acid nmol/L } \\
\text { Mean } \pm S . D\end{array}$} & \multicolumn{2}{c|}{$\begin{array}{c}\text { Triglycerides nmol/L } \\
\text { Mean } \pm S . D\end{array}$} \\
\hline & Fasting & Postprandial & Fasting & Postprandial & Fasting & Postprandial \\
\hline $\mathrm{gPA}(8)$ & $70 \pm 6$ & $70 \pm 5$ & $0.7 \pm 0.06$ & $0.73 \pm 0.02$ & $3 \pm 0.4$ & $2.5 \pm 0.5$ \\
\hline $\mathrm{gPB}(8)$ & $150 \pm 10.1$ & $60 \pm 2$ & $0.9 \pm 0.06$ & $0.61 \pm 0.03$ & $3.6 \pm 0.1$ & $1.5 \pm 0.1$ \\
\hline $\mathrm{P} 2$ & $<0.05$ & $<0.05$ & $<0.05$ & $<0.05$ & $>0.05$ & $<0.05$ \\
\hline $\mathrm{P} 3$ & $<0.05$ & $<0.05$ & $<0.05$ & $<0.05$ & $>0.05$ & $<0.05$ \\
\hline $\mathrm{gPC}(8)$ & $180 \pm 5.2$ & $190 \pm 2$ & $0.120 \pm 0.05$ & $0.150 \pm 3$ & $3.2 \pm 0.5$ & $5 \pm 0.1$ \\
\hline $\mathrm{Pl}$ & $<0.05$ & $<0.05$ & $<0.05$ & $<0.05$ & $>0.05$ & $<0.05$ \\
\hline
\end{tabular}


Table (2) : Effect of Ghrelin injected i.c.v for 6 days on plasma level of glucose, FFAs and triglycerides .

\begin{tabular}{|c|c|c|c|}
\hline & $\begin{array}{c}\text { Glucose mg/dl } \\
\text { Mean } \pm \text { S.D }\end{array}$ & $\begin{array}{c}\text { FFAs nmol/L } \\
\text { Mean } \pm \text { S.D }\end{array}$ & $\begin{array}{c}\text { Triglycerides nmol/L } \\
\text { Mean } \pm \text { S.D }\end{array}$ \\
\hline $\mathrm{gPA}(8)$ & $124.4 \pm 6$ & $0.7 \pm 0.06$ & $24 \pm 0.4$ \\
\hline $\mathrm{gPB}(8)$ & $131.8 \pm 7.8$ & $0.6 \pm 0.1$ & $23 \pm 0.1$ \\
\hline $\mathrm{P} 2$ & $<0.05$ & $<0.05$ & $<0.05$ \\
\hline $\mathrm{P} 3$ & $<0.05$ & $>0.05$ & $>0.05$ \\
\hline $\mathrm{gPC}(8)$ & $129 \pm 2.6$ & $0.5 \pm 0.04$ & $14 \pm 0.2$ \\
\hline $\mathrm{P} 1$ & $>0.05$ & $<0.05$ & $<0.05$ \\
\hline
\end{tabular}

Table (3): Effect of Ghrelin injected i.c.v for 6 days on the rats body weight, epididymal WAT tissue weight gain and triglyceride concentration in the epididymal WAT tissue.

\begin{tabular}{|c|c|c|c|}
\hline & $\begin{array}{c}\text { Body weight } \\
(g \mathrm{~m}) \\
\text { Mean } \pm \mathrm{S} . \mathrm{D}\end{array}$ & $\begin{array}{c}\text { Epididymal WAT (gm) } \\
\text { tissue weight gain } \\
\text { Mean } \pm \mathrm{S} . \bar{\delta}\end{array}$ & $\begin{array}{c}\text { Triglyceride concentration in } \\
\text { epididymal WAT tissue mg/dl } \\
\text { Mean } \pm S .0\end{array}$ \\
\hline $\mathrm{gPA}(8)$ & $300-400 \mathrm{gm}$ & 1.5 & $20 \pm 5$ \\
\hline $\mathrm{gPB}$ & $300-400 \mathrm{gm}$ & 1.5 & $20 \pm 3$ \\
\hline $\mathrm{P} 2$ & $<0.05$ & $<0.05$ & $<0.05$ \\
\hline $\mathrm{P} 3$ & $>0.05$ & $>0.05$ & $>0.05$ \\
\hline $\mathrm{gPC}$ & $500-600 \mathrm{gm}$ & 2.5 & $80 \pm 20$ \\
\hline $\mathrm{P} 1$ & $<0.05$ & $<0.05$ & $<0.05$ \\
\hline
\end{tabular}


Table (4): Effect of Ghrelin injected i.c.v for 6 days on mRNA expression of the lipoprotein lipase enzyme, carnitine palmitoyl transferase la, UCP1 and UCP2 in epididymal WAT.

\begin{tabular}{|c|c|c|c|c|c|c|c|c|}
\hline & \multicolumn{2}{|c|}{$\begin{array}{l}\text { Lipoprotein } \\
\text { lipase enzyme } \\
\text { nglgram tissue }\end{array}$} & \multicolumn{2}{|c|}{$\begin{array}{c}\text { Carnitine palymitoyl } \\
\text { transferase la } \\
\text { nolgram tissue }\end{array}$} & \multicolumn{2}{|c|}{$\begin{array}{c}\text { UCPI } \\
\text { nglgram tissue }\end{array}$} & \multicolumn{2}{|c|}{$\begin{array}{c}\text { UCP2 } \\
\text { ng/gram tissue }\end{array}$} \\
\hline & $\begin{array}{l}\text { Mean }= \\
\text { S.O }\end{array}$ & $\begin{array}{c}\% \\
\text { control }\end{array}$ & Mean $\approx S . D$ & $\begin{array}{c}\% \\
\text { control }\end{array}$ & $\begin{array}{c}\text { Mean } \pm \\
\text { S.D }\end{array}$ & $\begin{array}{c}\% \\
\text { control }\end{array}$ & $\begin{array}{c}\text { Mean } \pm \\
\text { S.D }\end{array}$ & $\begin{array}{c}\% \\
\text { control }\end{array}$ \\
\hline $\mathrm{gPA}(8)$ & 7 & 100 & 0.8 & 100 & $40 \div 10$ & 100 & $3.5 \pm 0.5$ & 100 \\
\hline $\mathrm{gPB}(8)$ & 7.7 & 10 & $0.5 \pm 0.02$ & 10 & $40 \pm 15$ & 10 & $3.5 \pm 0.4$ & 0.2 \\
\hline P2 & \multicolumn{2}{|c|}{$<0.05$} & \multicolumn{2}{|c|}{$<0.05$} & \multicolumn{2}{|c|}{$<0.05$} & \multicolumn{2}{|c|}{$<0.05$} \\
\hline P3 & \multicolumn{2}{|c|}{$>0.05$} & \multicolumn{2}{|c|}{$>0.05$} & \multicolumn{2}{|c|}{$>0.05$} & \multicolumn{2}{|c|}{$>0.05$} \\
\hline $\mathrm{gPC}(8)$ & 20 & 200 & 0.2 & 60 & $16 \pm 5$ & 60 & $5.5 \pm 0.3$ & 50 \\
\hline $\mathrm{Pl}$ & \multicolumn{2}{|c|}{$<0.05$} & \multicolumn{2}{|c|}{$<0.05$} & \multicolumn{2}{|c|}{$<0.05$} & \multicolumn{2}{|c|}{$<0.05$} \\
\hline
\end{tabular}

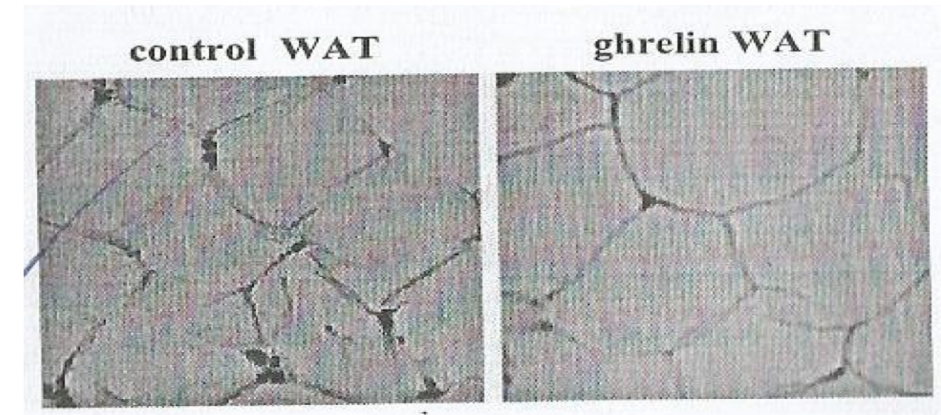

\section{Histological analysis of adipose tissue}

Epididymal WAT adipose tissue injected with ghrelin for 6 days show adipocytes hypertrophy as compared with control WAT. 

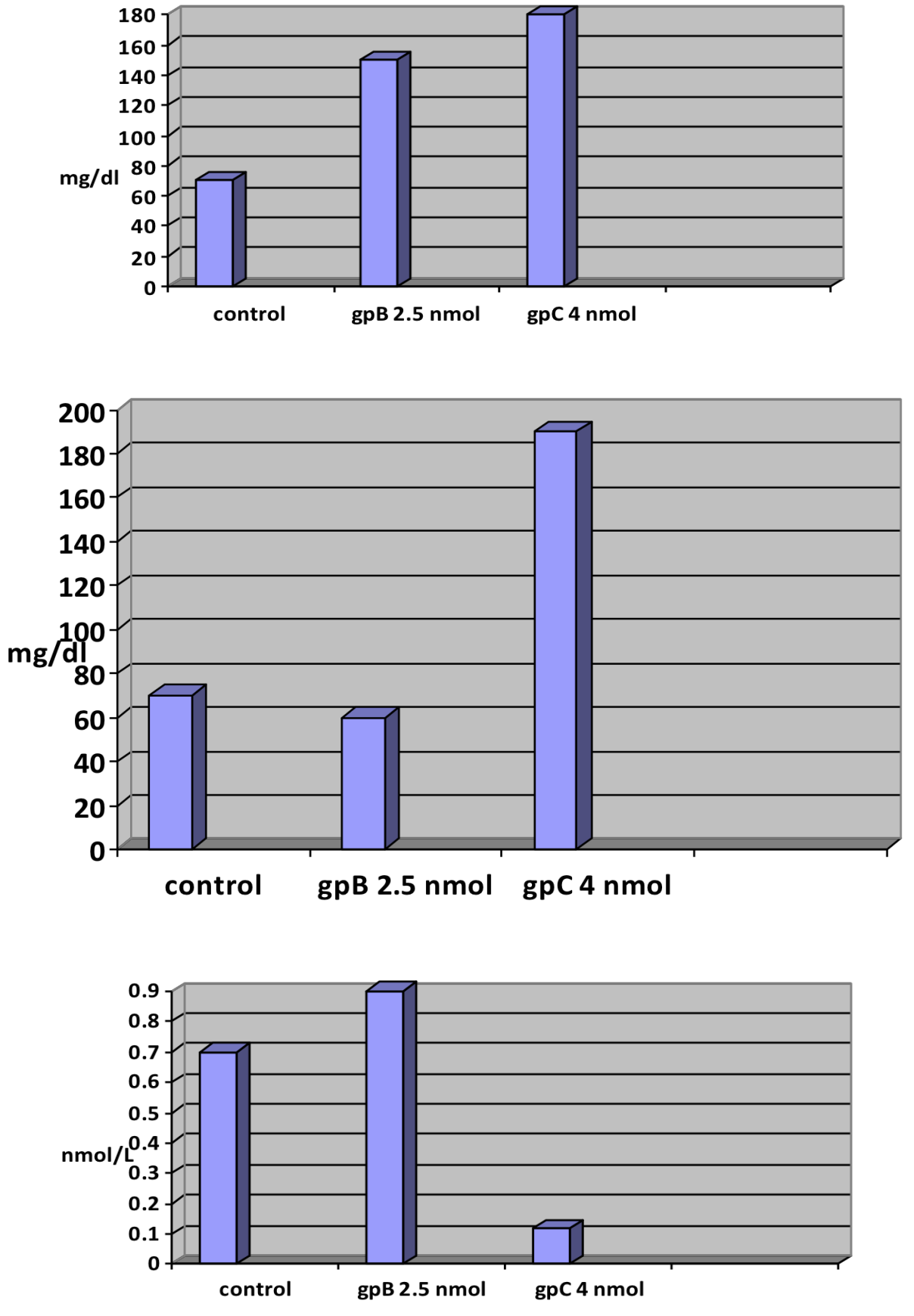

MANSOURA MEDICAL JOURNAL 

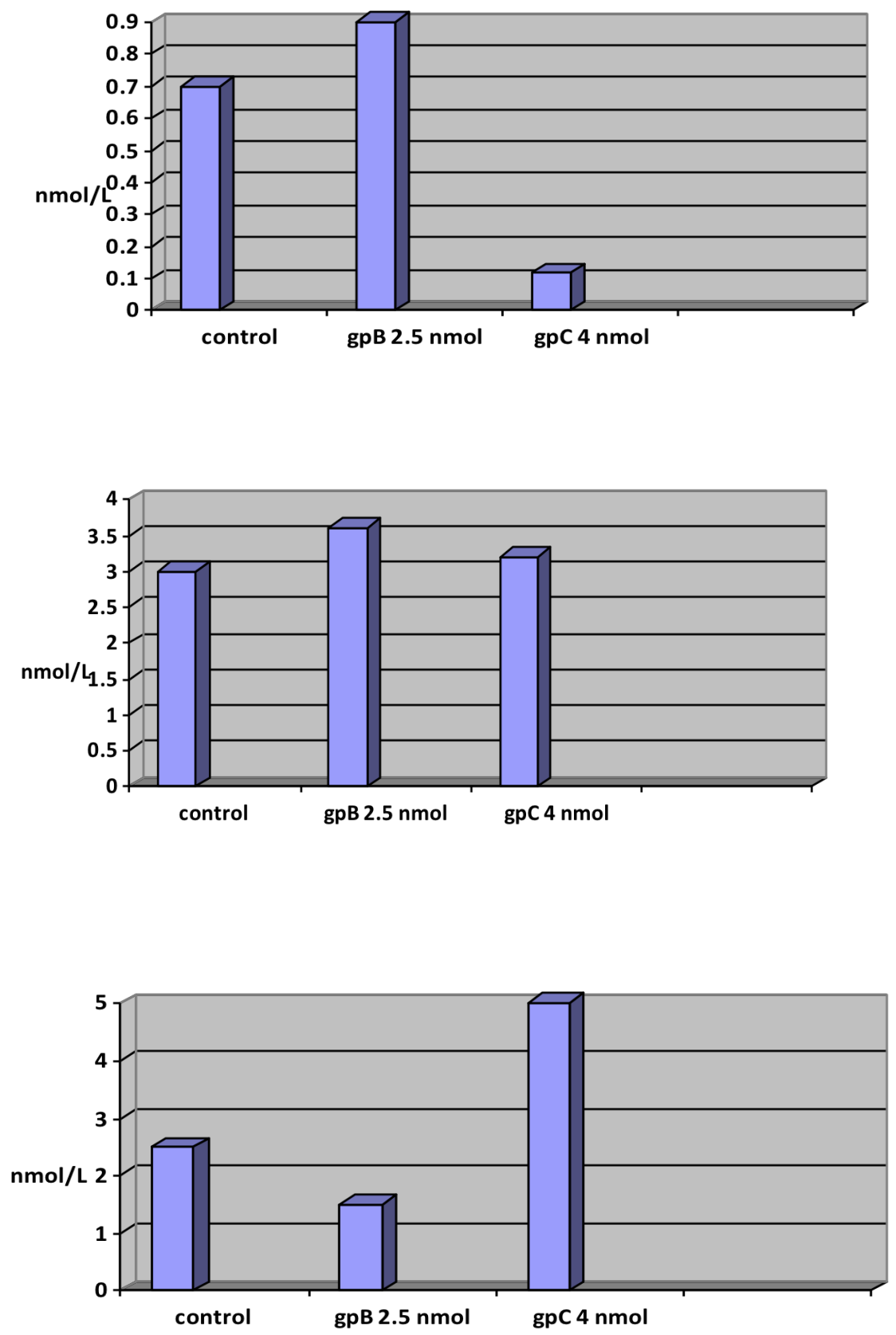

Vol. 44, No. 1 \& 2 Jan. \& April, 2015 

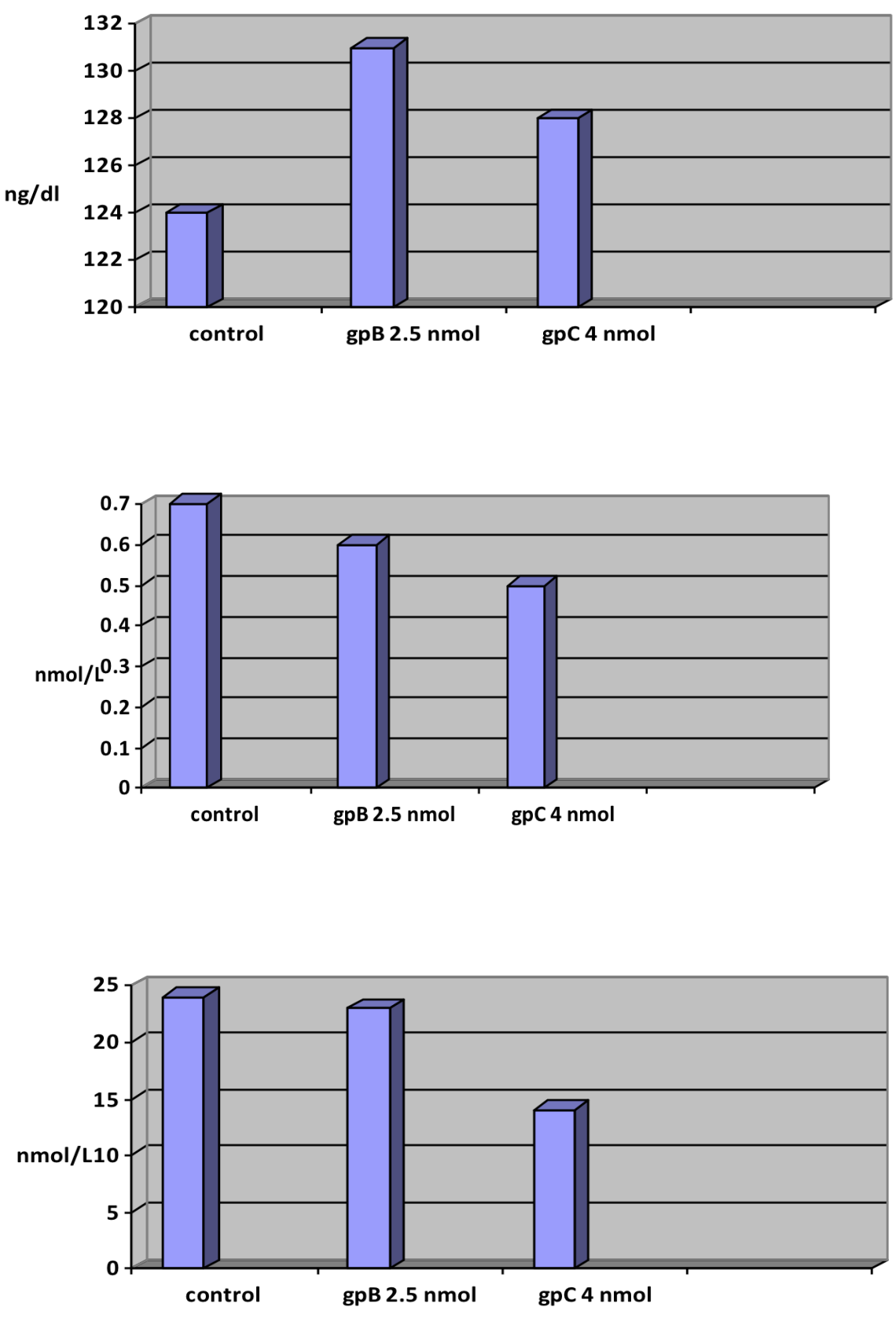

MANSOURA MEDICAL JOURNAL 

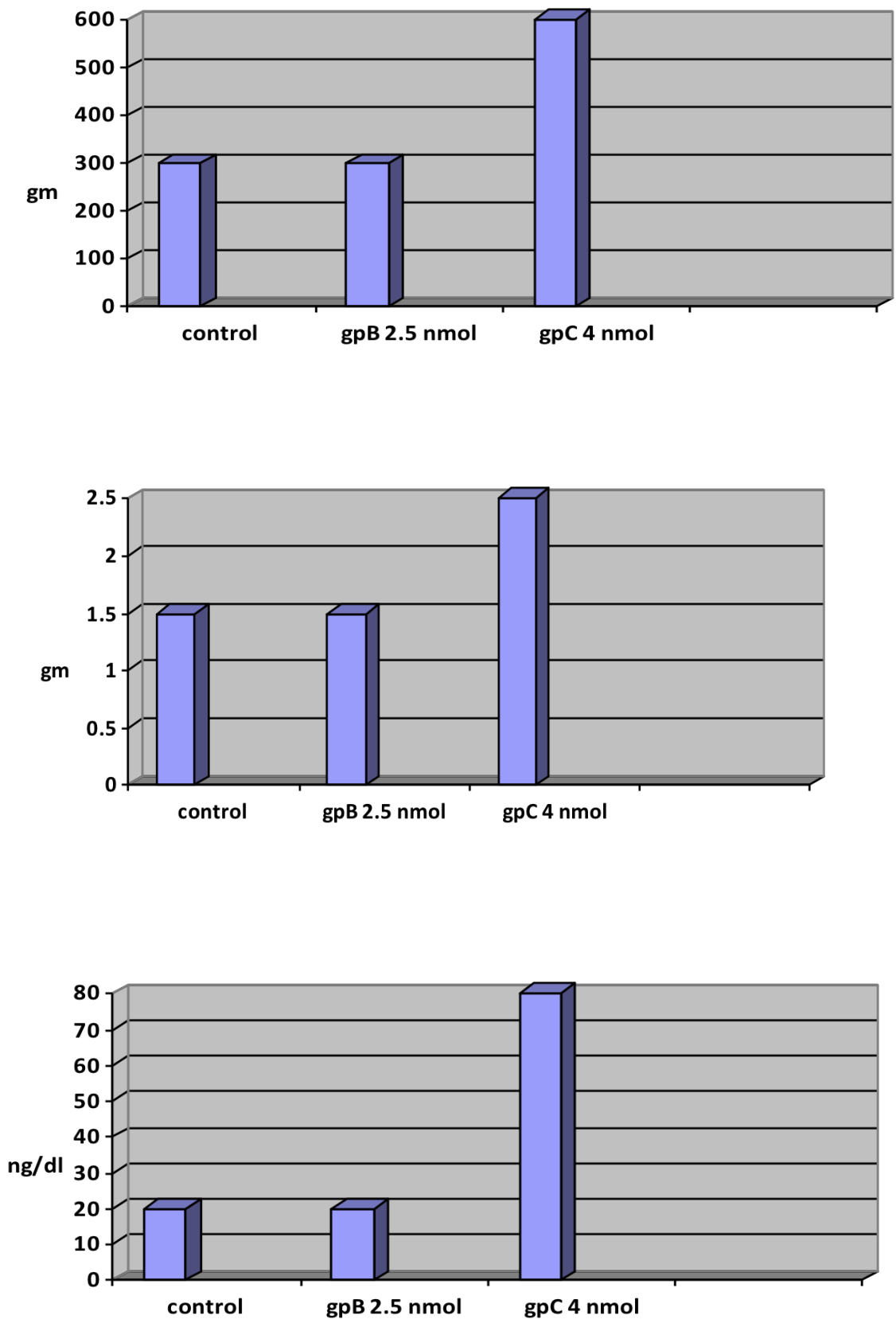

Vol. 44, No. 1 \& 2 Jan. \& April, 2015 

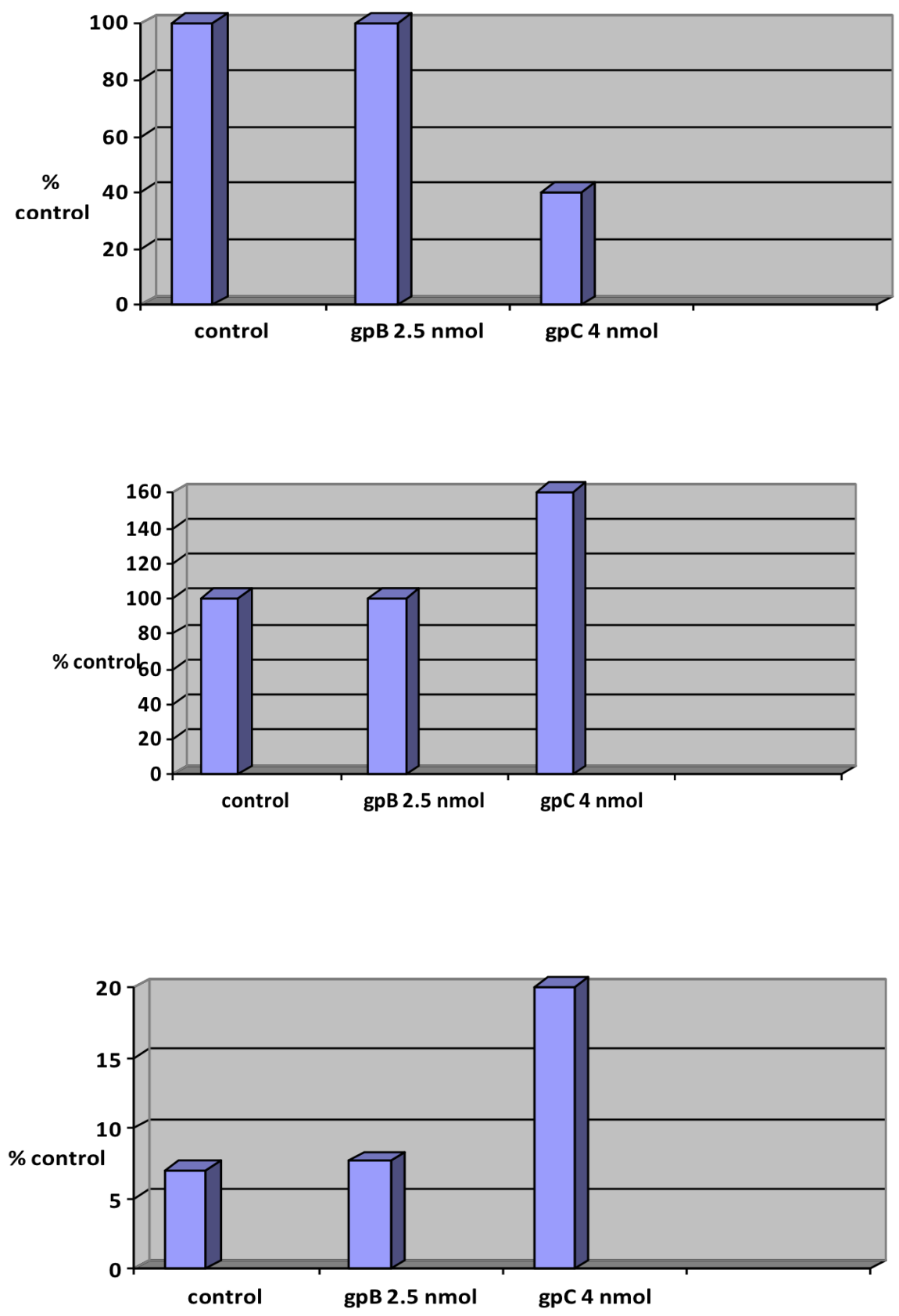

MANSOURA MEDICAL JOURNAL 




\section{DISCUSSION}

Role of central ghrelin in maintaining energy homeostasis

In our present work As regard the plasma glucose level following the acute injection of ghrelin intracerbroventricular, In the physiological dose in the fasting state : there was a significant increase in the plasma glucose as compared with the control group (gpA) . This hyperglycemic effect caused by central ghrelin administration during the fasting state can be explained by one or more of the followings :

- Ghrelin has been shown to activate glucose sensory neurons in the brain stem and by a central mechanism mediates a decrease in insulin release from the pancreatic islets. Dorsal vagal complex contain ghrelin sensitive neurons and the parasympathetic nerve fibers originating from dorsal vagal complex modulates the Vol. 44, No. 1 \& 2 Jan. \& April, 2015 pancreatic secretion of insulin (12).

- Also can be explained by a strong growth hormone releasing effect and or through induction of hepatic glucose production (12). The physiological relevance of increasing plasma glucose during the fasting state is : to maintain an available glucose in the blood to supply the vital organs : the heart and the brain during starvation. This physiological significance was shown by several studies who reported that total ghrelin varied with the feeding status during the waking period: rising before a meal and declining directly following a meal (12).

In the pharmacological dose:

The plasma glucose during the fasting state showed significant increase as compared with the control group. The underlying mechanism of this result could be : 
- An acute suppression of glucose disposal through reducing insulin sensitivity or suppression of insulin release from the pancreas.

- A direct stimulatory effect of hepatic glycogenolysis.

This result is in agreement with the work of (12 and 13). In those works a rapid hyperglycemic effect was demonstrated after injection of a bolus dose of ghrelin which preceded a more transient suppression of insulin levels.

In our present work in the postprandial state : The physiological dose showed significant decrease in glucose level as compared with the control group (gpA). This can be explained by :

- An increase in insulin stimulated glucose uptake both in adipose tissues and skeletal muscles, the physiological significance of such effect that : the increase in glucose uptake following a meal especially in the adipose tissues works to provide substate availability for replenishing fat stores which was utilized during the period of starvation. This demonstrate a subtle effect of ghrelin in maintaining energy balance. As ghrelin was found to be high in lean subjects and patients with anorexia nervosa and lower in obese subjects and in diabetic patients with high body mass index which may be a compensatory response.

Our work is in agreement with the work of (14) who demonstrate an increase in insulin stimulated glucose uptake both in adipose tissue and skeletal muscles following postprandial ghrelin administration.

In a contradictory of our results those reported by (15 and 1) who found that blockade of Acyl ghrelin in postprandial periods as well as ghrelin deficiency have been shown to improve insulin response of rodents to glucose challenge.

In our present work in the pharmacological dose in the postprandial state : there was significant increase in the plasma glucose level as compared with the control group (gpA): The persistent hyperglycemia in the postprandial state following the hyperglycemia observed in the fasting state suggests that : following the acute suppression of glucose disposal perhaps through reduced

MANSOURA MEDICAL JOURNAL 
insulin sensitivity, there was an increase in hepatic glucose production (12). Also the results highlight the strong diabetogenic effect of ghrelin when it is present in high serum level.

As regard the plasma free fatty acids following acute injection of ghrelin intracerebroventricular.

In our present work in the physiological dose in the fasting state : the plasma free fatty acids showed significant increase as compared with the control group (gpA). The underlying mechanism and physiological significance is :

- Decreased FFA oxidation (16) and this is supported by the work of (14). This is may be related to changes in metabolism favouring decreasing substrate oxidation and decreasing energy expenditure by the various body cells : On the opposite side in the postprandial state in the physiological dose, The plasma free fatty acids showed significant decrease as compared with the control group (gpA) which could be due to an anabolic action which is similar to growth hormone perphas through acting on similar receptors (16).

- Also ghrelin may act as a cofactor for growth hormone to ensure the provision of calories perhaps through both glucose and FFAs oxidation postprandialy to provide calories required for growth and repair in the various body sites. This result is in agreement with the work of (17)

\section{In the pharmacological dose:}

There was a significant decrease in plasma free fatty acid in the fasting state and in the postprandial state which could be explained by : It is most probably used for denovo triglyceride synthesis.

As regard the effect of acute injection of ghrelin intracerebroventricular on the plasma level of triglycerides.

In our present work in the physiological dose in the fasting state:

The plasma level of triglycerides showed non significant change state as compared with the control group (gpA). While in the postprandial states the plasma triglycerides showed a significant decrease also as compared with the control group (gpA). The decrease in the postprandial state could be explained by an increase in triglyceride clearance which serve to replenish th energy 
stores. Thus reverse the -ve energy balance which had been occurred in the fasting state.

In the pharmacological dose : In the fasting state

The plasma triglycerides showed non significant change as compared with the control group

In the postprandial state: the plasma triglycerides showed a significant increase. This increase could contribute to the diabetogenic of ghrelin when present in high concentration in the blood.

Effect of chronic ghrelin administration intracerebroventricular for 6 days on body weight : In the physiological dose there is no effect on body wt. While effect of an increased body wt with the pharmacological dose was evident.

In our present work as regard the epididiymal white adipose tissues (WAT) change caused by chronic ghrelin administration.

There was an increase in triglyceride content, increase in the weight of WAT and also there was adipocyte hypertrophy which was shown by histological analysis.

The high concentration of ghrelin caused by the administration of the pharmacological dose anatagonize the feedback mechanism which regulate the ghrelin concentration :

In our present work the increase in body weight together with promotion of adipogenesis could be mediated by

- Stimulation of growth hormone secretion by the anterior pituitary the growth hormone leads to adipocyte hypertrophy (18)

- Ghrelin exert a small but significant influence over the secretion of the majority of adenohypophyseal hormones :

- It elicit a dose dependent increase in prolactin secretion in humans and rats (19). Any effect of prolactin an adipocytes differentiation and function appears to be indirect (20 and 12).

- Also similarity ghrelin activate the hypothalamo pituitary adrenal axis, increasing the activity of corticotropin releasing hormone (21). Thus elevating circulating cortisone: the adrenal glucocorticoids are powerfully adipogenic hormones promoting the differentiation of preadipocytes into terminally differentiated adipocytes (22).

Also the increased body weight

MANSOURA MEDICAL JOURNAL 
effect caused by the pharmacoligcal dose of ghrelin could be mediated by

- Neuroendocrine circuits within the CNS that are known to regulate appetite and food intake have also been shown to control peripheral adipogenesis.

- The hypothalamic melanocortin system including the neuropeptide agouti related protein and $\alpha$ melanocyte stimulating hormone is one of the circuits involved in the CNS control of peripheral glucose homeostasis (23). Hypothalamic NPY also affect peripheral glucose and lipid metabolism (23)

. Both the melanocortin system and NPy are known hypothalamic targets of the gastrointestinal hormone and putative neuropeptide ghrelin (25). At the cellular level ghrelin promotes adipogenesis through

- Ghrelin augments glycerol 3 phosphate dehydrogenase activity and enhances the expression of PPAR $\gamma \mathrm{s}$ mRNA (peroxisome proliferators activated receptor a master cofactor of the adiposcyte differentiation process and accelerates the appearance of mature adiocytes) (21)

- Elevating circulating ghrelin in- duces adipocytes enlargement (22)

- I.C.V. ghrelin upragulates the lipoprotein lipase enzyme (the fat storage enzyme) and down regulates the expression of the fat oxidation promoting enzyme (CPT1 $\alpha$ ) In epididymal fat (23).

- Also by phosphorylation of MAP kinase leads to up regulations of PPAR (24). All these effects is in agreement with the work of (24) on the other site the work of (22) demonstrate an inhibitory effect of chronic central ghrelin on adipogenesis. An overview of the physiological central ghrelin in maintain energy balance could be the following :

- Control centers in the hypothalamus including the ventromedial hypothalamus arcuate nuclei and lateral hypothalamic area exhibit high expression of ghrelin and have long been known to respond to circulating signals to control the degree of adiposity and TGS storage and this is detected and regulated around a set point $(23$ and 16).

As regard plasma glucose level following central ghrelin injection for 6 days: 
In the physiological dose $(g p B)$ : particularly that in pancreatic islets

Showed significant decrease in could optimize the amount of insulin plasma glucose level as compared with the control group (gpA) and with the pharmacological dose $(\mathrm{gpC})$ : A role of acyl ghrelin in central reglulation of glucose homeostasis was described by (12). That the nucleus tractus solitareous (NTS) contain acylghrelin regulatory glucosensory neurons. The low plasma glucose observed in (gpB) could be attributed to :

- An increase in carbohydrate utilization rats. As ${ }^{(9)}$ found a significant increase in respiratory quotion following i.c.v ghrelin treatment of rats.

- Also majority of studies have shown that AG can amplify glucose stimulated insulin secretion by the pancreas (20). As a contradictory by the same authors that AG can retards glucose stimulated insulin secretion by pancreas but the concentration of $A G$ required to suppress insulin release was higher than the circulating level (20).

Thus it can be concluded that physiological concentration of ghrelin seems to have an insulinostatic function. Also that Ghrelin-GHSR system release to meet the systemic demand (9).

In the pharmacological dose the absence of an effect of ghrelin on plasma glucose level could be explained by :

- Although chronic central ghrelin infusion result in increase in glucose utilization rate of white and brown adipose tissues, it doesn't affect the skeletal muscle glucose utilization. Given the fact that the skeletal muscle is the main glucose consuming tissue. So this can explain the normal glucose level observed in our work (9).

As a regard the effect of ghrelin injected intracerebroventricular for 6 days on plasma free fatty acids

In our present work, in the physiological dose (gpB):

There was a significant increase in free fatty acids level in plasma under the physiological dose compared with the pharmacological dose. The underlying mechanism of such effect is :

Firstly centrally derived ghrelin enhances the sympathetic nervous system effect on adipocytes.

MANSOURA MEDICAL JOURNAL 
The sympathetic nervous system:

- Enhances lipolysis and NEFA release from the adipocytes, and this effect was found to be in proportions of number and activity of B2 and B3 adrenoceptors (25).

- It down regulates the expression of lipoprotein lipase enzyme activity (the fat storage enzyme) in white adipose tissue (25). This effect was found to be sensitive and related to the underlying nutritional states. So it seems to play a significant role to maintain energy balance (26). This is supported by the established and known findings that there is an enhanced sympathetic activity following eating which serves to increase energy expenditure thus guard againt the development of obesity.

Secondly Ghrelin has been shown to enhance leptin secretion (27). Leptin is a long term energy regulating factor. While ghrelin is a short term energy regulator. Thus there is a close link between the negative feedback long term energy storage signal and the short term energy insufficiency signal of ghrelin. Thus the number of adipocytes and their lipid storage activity are tightly regulated so that the individual body weight and fat distribution remain remarkably. Constant over periods of many years not only by peripheral determinants, but by also central determinants.

In this situation we must remember that: In the postprandial period ghrelin could enhance insulin sensitivity and could enhance insulin secretion from the pancreas by a central action. Where this effect is closely linked to the underlying energy and states. Insulin in such situation enhance lipogenesis and promotes TAG storage through:

- Insulin increases the expression of PPAR $\gamma$ (peroxisome proliferators ) activated receptor that activate the appearance of mature adipocyte (25).

- It increases the uptake and esterification of NEFFAs coupled with the suppression of hormone sensitive lipase activity and subsequent inhibition of lipolysis.

- Insulin also enhances glucose uptake via Glut4 and de novo lipogenesis (28). All of these effects of insulin maintain a constant energy balance all as regard to the personal energy status.

- The overall effect of the centrally derived ghrelin under the physio- 
logical dose in conditions of +ve energy balance is to mediate fat lipolysis which seems to be a sympathetic effect or through the link of long term energy signal through leptin and the short term energy signal through ghrelin.

- While under certain conditions of -ve energy balance it promote fat storage which seems to be through insulin so these regulations is related to feedings and energy status

As regard the plasma level of triglycerides following 6 days injection of ghrelin:

In the physiological dose there was non significant effect as compared with the control group (gpA).

As regard the expression of mRNA of lipoprotein lipase enzyme, carnitine palmitoyl transferse $\alpha$, UCP1, and UCP2 in epididdymal WAT :

In the physiological dose there was non significant effect as compared with the control group (gpA)

As regard the effect of ghrelin injected intracerebroventricular on plasma free fatty acids, triglycerides : In the pharmacological dose ( $g p C)$ :

- There was non significant effect on plasma free fatty acid level as compared with the control group (gpA).

- On the other hand there was significant decrease in triglyceride plasma level as compared with the control group (gpA). And non significant change in plasma FFAs The underlying significance of such effect is that chronic pharmacological dose of ghrelin increases fat storage by promoting TG import thus promote adipogenesis. As regard the effect on the mRNA level of the fat oxidation promoting enzyme, carnitine palmitoyl transferase $1 \alpha$ (CPT$1 \alpha$ ) and the mRNA of the fat storage enzyme, lipoprotein lipase (LPL).

As a support of this explanation (enhancement of adipogenesis) in our work there was significant increase in mRNA level of LPL and significant decrease of mRNA of CPT1 $\alpha$ in (gpB) both as compared with the control group (gpA). The significance of such effects is to inhibit FA oxidation while enhancing its import within the adipocytes with subsequent increase in denovo triglyceride synthesis thus promote adipogenesis. These results are in agreement with the work of (9) As re-

MANSOURA MEDICAL JOURNAL 
gard the effect of ghrelin injected intracerebroventricular on the mRNA level of UCP2 in epididymal fat:

In our work in the pharmacological dose (gpC) we noticed a significant increase in mRNA level of UCP2 as compared with the control group (gpA). Although UCP2 is not much involved in thermogenesis it may serve the following functions: (4 and 2).

- Under conditions of decreasing UCP1 expression as what observed in our present work. UCP2 increases in WAT tissue which can be suggested to be a compensatory mechanism

- Also the positive energy balance caused by the pharmacological dose of ghrelin observed in our work it is induced by hunger and appetite as it is expressed in NPy and AGRP neurons, and UCP2 contribute to this effect.

- Also UCP2 promotes glucose uptake in WAT as a substrate of fat synthesis.

As regard the effect of ghrelin injected intracerebroventricular on the UCP1 mRNA level in epididymal fat: In the pharmacological dose $(g p C)$ : There was significant decrease in
mRNA expression as compared with the control group (gpA) while in The physiological dose (gpB) there was non significant change as compared with the control group (gpA): such effect could be explained by (29 and 30).

- Discrete hypothalamic nuclei and various neuropeptides as ghrelin regulates energy expenditure. This by affecting efferent sympathetic nerve activity.

- Central administration of NPY (a mediator of ghrelin signaling) suppresses sympathetic nerve activity. Also the long term effect of ghrelin to promote a +ve energy balance highlights the presence of other mechanism by which large long lasting dose of ghrelin decrease energy expenditure.

So in conclusion, chronic central ghrelin could promote adipogenesis by decrease in energy expenditure through decreasing the expression of UCP1 in WAT. These results is in agreement with the work of (9).

\section{Conclusion}

We can conclude in our work that central ghrelin maintain energy balance by :

- Increasing both fasting glucose 
and free fatty acids plasma level to supply important structures such as the brain and the heart state.

- While postprandially the high glucose and FFA is used to replenish energy stores which was depleted during the fasting state.

So we advice obese patients or persons who do diet regimen to have small diets at intervals and avoid fasting for prolonged periods as this enhances the storage of this metabolic substrate mobilized by ghrelin during fasting state as neutral fat postprandially.

Central ghrelin in the pharmacological dose which resemble the increments in ghrelin concentration postprandially enhance triglyceride storage by lowering the level of the enzyme carnitine palmitoyl tranferase $1 \alpha$ (the enzyme responsible for lipid export).

While increasing the level of the enzyme lipoprotein lipase (the enzyme responsible for lipid storage. Central ghrelin in its pharmacological dose lowers the level of UCP1 in adipose tissue while raises the level of UCP2 thereby decrease the overall energy expenditure. Central ghrelin in pharmacological dose have strong hyperglycemic effect and increases the triglyceride content of adipose tissues and increases its concentrations in plasma thus by this it causes a positive energy balance and worsens a diabetic state. So blocking of ghrelin by Ghrelin blockage can be a new approach to prevent hazards of diabetes and obesity. Especially in persons with high plasma ghrelin concentration or those who have high ghrelin responsive tissue.

\section{REFERENCES}

1. Aitman T.J., Glazier, A.M., Wallace, C.A., Cooper, L.D., Norasworthy, P.J., Wahid, F.W, etal., (1999) : Identification of CD36 (fat) as an insulin resistance gene causing defective fatty acid and glucose metabolism in hypertensive rats. Nat Genet, 21 :76-83.

2. Andrews, Z.B., Diano, S., Horvath, T.L., (2005) : Mitochondiral uncoupling proteins in the C.W.S in support of function and survival. Na Rev neurosci, 6:829-840.

3. Nicholls, D.G., Locke, R.M., (1984) : Thermogenic mechanisms in brown fat. MANSOURA MEDICAL JOURNAL 
Physiol Rev, 64:1-64.

4. Bouchard, C., Perusse, L., Chagnon, Y.C., Warden, C., Ricquire, D., (1997) : Linkage between markers in the vicinity of the uncoupling proteins 2 gene and resting metabolic rate in humans Hum Mol Genet, $6: 1887-9$.

5. Van der Toorn F.M., Janssen, J.A.M.d., de Herder, W.W., Broglio, F., Ghigo E., Van der lely, A.J., (2002) : ghrelin production doesn't substantially contribute to systemic ghrelin concentrations: a study in two subjects with active acromegaly. Eur J Endocrinol, 147: 195-9.

6. Kojima, M. Hosoda, H., Date, Y., Nakazato, M., Matsu, H., Kangawa, K., (1999) : Ghrelin is a growth hormone releasing acylated peptide from stomach nature, 402:656-60.

7. Davies, J.S, Kotokorpi, P., Ecceles, S.R., Barnes, S.,
K., Tokarczuk, P.F., Allen, S.K., etal., (2009) : Ghrelin induces abdominal obesity via GHS-R dependent lipid retention, Mol Endocrinol, doi: 10:1210/me 20080432.

8. Cowley, M.A., Smart, J.L., Rubinstein, M. Cerdan, M.G., Diano,S., Horvath, T.L., etal., (2001) : Leptin activates anorexigenic POMC neurons through neural network on the arcuate nucleus Nature: 411 : 480-4.

9. Carrillo, C.T., Wiedmer, P., Cettour-Rose, P., Nogueiras, R., Pe rez.-Tilve, D., Pfluger, P. etal., (2006) : Ghrelin action in the brain controls adipocyte metabolism. The Journal of clinical investigation,

116:3

(7)1983-1993.

10. Tschop, M., Flora, D.B, Mayer, T.P., Heiman, M.L., (2002) : Hypophysectomy prevents ghrelin induced adiposity and increases gastric ghrelin secretion in rats. Obes Res, 10 : 
$991-9$.

11. Qian, H., Azain, M.J. Compton, M.M., Hartzell, D., L., Hausman, G.J., Baile, C.A. (1998) : Brain administration of leptin causes dilation of adipocytes by apoptosis Endocrinology,: 139:791-4.

12. Objci, S., Rossetti, L., Minireview: Nutrient sensing and the regulation of insulin action and energy balance. Endocrinology. 44 : 5172-5178.

13. Guan, X., M., Yu, H., Palyha, O.C., Mckee, K.K., Feighner, S.D., Sirinath singhji, D.J.S., etal. (1997) : Distribution of mRNA encoding the growth hormone secretagogue receptors in brain $\alpha$ peripheral tissues. Mol Brain Res, 48:23-9.

14. Broglio, F., Arvat, E., Benso, A., Gottero, C., Muccioli, G., Papotti, M., etal. (2001) : Ghrein a natural $\mathrm{GH}$ secretagogue produced by the stomach, induces hyperglycemia and reduces insulin secretion in humans. J clin Endocrinal metab, $86: 5083-6$.

15. Aeosio, M., Ronchi, C.L., Gebbia, C., Cappiello, V., Beck-Peccoz, P., Peracchi, M. (2003) : Stimulatory effects of ghrelin on circulating somatostatin and pancreatic polypeptide level. $\mathrm{J}$ clin Endocrinal metab : 88: 701- 4.

16. Asakawa, A., Inui, A., Kaga, T., Yazuriha, H., Nagata, T., Veno, N., Makino, S., Fujimiya,M., Nii jima, A., Fujino, M.A. Kasuga, M. (2001) : Ghrelin is an appetite stimulatory signal from stomach with sturcutral resemblance to motilin. Gastroenterology, 120:337345.

17. Sun,Y. Asnicar, M., Saha, P.K., Chan, L., Smith, R.G., (2006) : Ablation of ghrelin improves the diabetic but not the obese phenotype of ob/ob mice. Cell Metab :3i 379-86.

MANSOURA MEDICAL JOURNAL 
18. Giorgenio, F., Laviola, L., Eriksoon, J.W. (2005) : Regional differences of insulin action and adipose tissue, Insights from in vivo and in vitro studies- Acta physiol scand :183:13-30.

19. Fleint, D.J., Binart, N., Kopchick, J., Kelly, P., (2003) : Effect of growth hormone and prolactin on adipose tissue development and function. Pituitary, 6-971102.

20. Freemark, M., Fleenor, D., Driscoll, P., Binart Kelly, P.A. (2001) : Body weight and fat deposition in prolactin receptor deficient mice. Endocrinology, 142: 532-7.

21. Thomas, G.B., Fairhall, K.M., Robinson, I.C.A.F. (1997) : Activation of the hypothalamo pituitary adrenal axis by the growth hormone secretagogue, G.H. releasing peptide- 6 in rats Endocrinology : 138: $1585-91$.

22. Wortley, K.E., etal., (2005) :
Absence of ghrelin protects against early onset obesity. J Clin. Invest., 115:3573-3578.

23. Yang, S., Bjorntorp, P., Liu, X., Enden, S., (1996) : growth hormone treatment of hypophysectomized rats increase catecholamine induced lipolysis and the number of beta-adrenergic receptors in adipocytes.: no differences in the effects of growth hormone on different fat pads. Obes Res, 4: 471-8.

24. Egawa, M., Yashimatsu, H., Bray, G.A., (1991) : Neuropeptide $Y$ suppresses sympathetic activity to interscapular adipose tissue in rats. Am.J.physiol., $260 \mathrm{R}$ 328-R 334.

25. Torsello, A., Scibona, B., Leo, G., Breesciani, E., Avallone, R., Bulgarelli, I. etal., (2003) : Ontogeny and tissue specific regulation of ghrelin mRNA expression suggest that ghrelin is primarily in volved in the control of extraendo- 
crine functions in the rat.

Neuroendocrinology, 77:91-9.

26. Mozied, A.M. etal., (2003) : Ghrelin is released from rat hypothalamic explants and stimulates corticotrophin releasing hormone and argining-vasopression Horm. Metab. Res, 407 : 908-913.

27. Krief, S., Lonnq vist, F., Raimbault, S., Baude, B., van spronsen, $A$. etal., (1993) : Tissue distribution of b3 adrenergic receptor mRNA in man. J clin Invest, 91:344-349.

28. Tetsuo Tsubone, Takoyuki Masaki, Isao Katsoragi, Katsuhiro Tanaka, Tetsuga Kakuma, Hironobu Joshimatsu, (2005) : ghre- lin regulates adiposity in white adipose tissue and UCP1 mRNA Expression in brown adipose tissue in mice.:130:97-103

29. Frunhbeck, G., Agaudo; M., Martinez. J.A. (1997) : In vitro lipolytic effect leptin on mouse adipocytes evidence for possible autocrine, paracrine role of Leptin. Biochem Biophys Res commun, 240:590-4.

30. Choi, K., Rhoh, S., G., Hong, Y-H, Sherestha, Y.B., Hishikawa, D., Chen, C., etal., (2003) : The role of ghrelin and growth hormone secretagogue receptor on rat adipogenesis. Endocrinology, 144 : $754-9$. 


\title{
الملحــص العربـى
}

\section{تأثير هرمون الجهر لين الذى يفرز من المخ فى الحفاظ \\ على مستوى الطاقة فى الجسيه.}

\author{
ملخص العمل بالبحث :

 \\ ثبات مستوى الطاقة في الجسمى وعملية الأيض بالخلايا الدهنيـة في كلا المجموعتين الرئيسيتين \\ كان هناك ب مـجموعات فرعية :

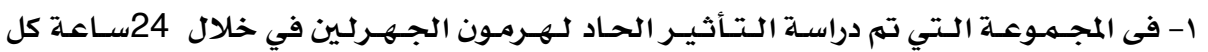 \\ مجموعة كانت تشمل الآتى : \\ - المجموعة أ (المجموعة الضابطة) : تم حقن محلول ملحي بجرعة (5 ML) \\ - المجموعة ب (المجموعة الفارماكولوجية) : تم حقن هرمون الجهرلين بجرعة (4 nmole) \\ - المجمـوعة س (المجمـوعة الفسيولوجية) : تم حقن هرمـون الجهرلـين بجرعة (2.5 nmol) فى كل \\ المجموعات ، عينات من الدم تم جمعها وقياس الآتي :

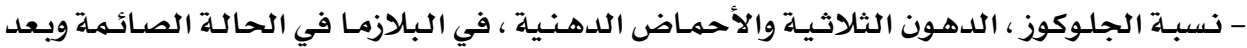 \\ الأكل \\ r- فى المجموعة التى تم حقنها لمدة 7 أيام : \\ - المجموعة أ (المجموعة الضابطة) : تم حقن محلول ملحى بجرعة (5 ML) \\ - المجموعة ب (المجموعة الفارماكولوجية) : تم حقن هرمون الجهرلين بجرعة (4 nmole)

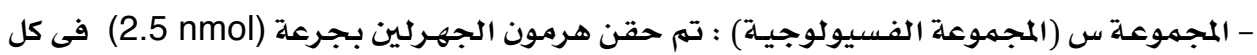 \\ المجموعـات : الدهون المحيطة بالبربخ تم جمعهها وقياس الآتي : كم الدهون الثثلاثيـة ووزنها وتم \\ قراءة النسيج وتحليله هستولوجيا في المجموعة ب بالمقارنة بالمجموعة الضابطة \\ كذلك فى كل المجـموعات تم قياس مستوى الجلوكوزوالأحماض الدهنية والدهون الثلاثية فى \\ البلازما وتم قياس مستوى الحمض النووى الراسل لكل من : \\ هرمون الليبوبروتين ليباز \\ هرمون الكاريتن بالميتويل ترانسفيراز ، UCP2 و Uروينيار ل
}


فى كل التجارب تم مقارنة بين الثلاث مجمموعات النتائج

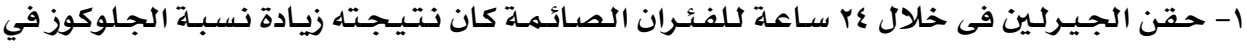
البلازما سواء كان في مجمموعة (س) أو مجمموعة (ب) وذلك بالمقارنة بالمجموعة (أ) . ولكن هناك زيادة معنوية في مستوى الجلوكوز في المجموعة (ب) أكثر من المجموعة (س) r- حقن الجـيـرلين فى خلال ع سـاعـة بعـد الأكل زاد مستـوى الجـلوكوز في المجـموعة (ب) وانقص


ب- كذلك بعد الأكل ، الفئران في المجموعة التي تم حقنها بالمجموعة (س) أعطت نقص في مستوى الجلوكوز فى البلازما بالمقارنة بالفئران التى تم حقنها بالمجموعة (ب) وذلك فى خلال عبساعة ع- الفئران الصائمسة اعطت زيـادة في مستوى الأحمـاض الدهنية في المجـموعة (س) والمجموعة (ب) وذلك بالمقارنة بالمجموعة (أ) وذلك في خلال عr ساعة ه- كذلك الفئران الصائمة فى المجموعة (س) المحقونة فى المجموعة (س) أعطت نقص فى مستوى الأحماض الدهنية فى البلازما بالمقارنة بالفئران بالمجموعة (ب) ج- بعد الأكل الفئران المحقونة بالجرعة (ب) أعطت زيادة في مستوى الأحماض الدهنية ونقص في مستوى الأحماض الدهنية بالجرعة (س) بالمقارنة بالمجموعة (أ) ، ذلك في خلال عب ساعة V- كذلك المجمهوعة بالمجمموعة (س) بعد الأكل أعطت نقص شـديد في مستوى الأحماض الدهنية بالمقارنة بالمجموعة (ب) وذلك في خلال عץ ساعة ^- الفئـران الصـائمسة أعطت تغـيـير في مستوى الدهـون الثلاثيـة بالمجهـوعة (ب) والمجهـوعة (س)

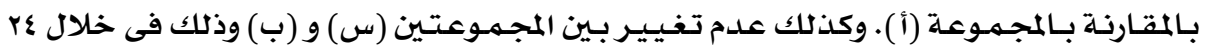
ساعة 9- بعد الأكل الفئران في المجموعة (ب) أعطت زيادة في مستوى الدهون الثلاثية ولكن في المجموعة (س) أعطت نقص في مستواها وذلك بالمقارنة بالمجموعة (أ) وذلك في خلال 24ساعة . كذلك الفئـران في المجـمـوعـة (ب) أعطت زيـادة في مسـتوى الـدهـون الثثلاثيـة في البـلازمـا بـالمقـارنـة بالفئران في المجموعة (س) وذلك في خلال عب ساعة. • ا- نتاج حقن الفـــران لمدة ج أيـام كان هـناك زيـادة فى مستـوى الحمض النـووي الكراسل للانزيه الخخاص بتخزين الدهون في الدهون المحيطة بـالبربخ فى المجموعة (ب) بالمقارنة بالمجموعة (أ) وعدم تغير فى ذلك فى الفئران فى المجموعة (س) ال- المجـهـوعـة المحقـونـة بـالجـرعة (ب) أعطت زيـادة فى مسـتوى الحـمض النـووي الدراسل لإنزيم 
الكارنتين بـالميتويل الخاص بتحليل الدهـون وذلك في الدهون المحيطة بـالبـربخ وعدم تغير فى

المجموعة المحقونة بالجرعة (س) بالنسبة للمجمموعة (أ)

با - المجمـوعة (ب) أعطت نقص فى مستوى الحمض النووي الراسل الخاص ب UCP1 وذلك في

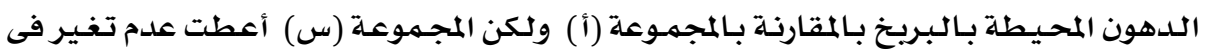

مستوى UCP1 بالمقارنة بالمجموعة (أ) ولكن زيادة معنوية بالمقارنة بالمجموعة (ب) با - المجموعة (ب) أعطت زيادة ملحوظة فى مستوى الحمض النووي الراسل دـ UCP2 فى الدهون المحيطـة بـالبربخ وذلك بـالمقـارنـة بـالمجمهوعة (أ) والمجـموعة (س) أعطت عدم تغييـر بالمقـارنة بالمجموعة (أ) ولكن نقص ملحوظ بالمقارنة بالمجموعة (ب). حقن هرمون الجهرلين لمدة 6 أيام

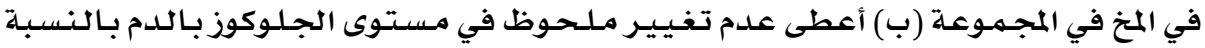
للمسجـموعـة (أ) ولكن المجمـوعة (س) أعطت زيـادة معـنويـة بـالمقـارنـة بالمجهموعة (أ) وعدم زيادة

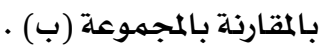
ع ا - المجمـوعة (ب) أعطت نقص مـلحوظ في مستوى الأحماض الدهنية وذلك بـالمقارنة بـالمجموعة (أ) والمجمهوعة (س) أعطت عـدم تغييـر بالنسبـة للهمجموعة (أ) ولكن زيادة بـالمقارنـة بالمجهموعة

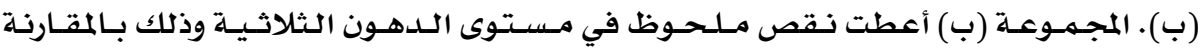
بـالمجمهوعة (أ) ولكن المجموعة (س) أعطت زيـادة ملحسوظة بـالنسبـة للمجسموعة (ب) ولكن عدم زيادة بالنسبـة للهمجموعة (أ) 10- المجموعة (ب) أعطت زيادة في وزن الجسهم بالنسبـة للمجسموعة (أ) ولكن المجـموعة (س) أعطت عدم تغير بالنسبـة للمجموعة (أ) ونقص بالمقارنة بالمجموعة (ب)

17 - المجسموعـة (ب) أعطت زيـادة فى وزن النسـيج الدهنى المحيط بـالبـربخ بالنسبـة للسهـهـوعة (أ)

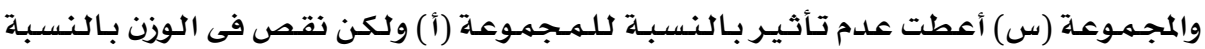

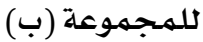
Vا - المجسموعة (ب) أعطت زيـادة معنـوية في مستـوى الدهـون الثلاثية في الدهون المحيطة بـالبريخ بالنسبـة للمهـمـوعة (أ) ولكن المجمـوعة (س) أعطت عدم تأثير بـالنسبـة للمسجمـوعة (أ) ولكن نقص بالنسبة للهمجموعة (ب) 11- تحليل النسيج الدهنى المحيط بـالبربخ في المجـموعة (ب) أعطى زيادة في حبيبات الدهون في النسيج مـع زيادة في حجم الخلايا الدهنية. 
من هذا البحثث يمكن تلخيص الآتى :

الجيرلين الذى يتمم افرازه من عدة امـاكن عن طريق تأثيره على بعض الأماكن في المخ وذلك في


بـالحفاظ على مستوى الدهون المخزونه بالجسهم. وذلك ريمـا يكون بـزيادة نسبـة الجلوكوز في حالة الصـيام وكذلك الأحمـاض الدهنيـة وهذا يجعـله متاح للأكسـلدة واستخدامـه كمنبـع للطاقة في هذه الحال وبـالتـالي يكون متاح ليمـد الأعضـاء الرئيسية في الجسسم كالمخ والقلب بـالطـاقة. ولكن بعد الأكل يساعد على تخزينها في صورة دهون وبـذلك يتم تعويض للمـخزون بالجسهم من الطاقة الذي تم فقده فى فترة الصيام وبهذه الطريقة يحافظ على ثبات مستوى الطاقة بالجسهم.

الجيـرلين يعمـل مـركزيـا عنـدمـا يحقن بـالجـرعة الفـارمـاكولوجـيـة. وذلك بـأن يـقوم بـتخزين

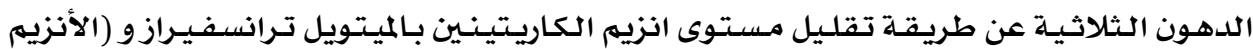
المسئـول عن تحـليـل الدهون ويـقوم بزيـادة انيزم الليبـوبـروتين ليبـاز (الانزيم المسئسول عن تخزين الدهون). وكذلك بهـذه الجرعة يقلل نسبـة UCP1 فى النسـيج الدهنى ويزيــ مستوى UCP2 ويكون له تأثير شـديد في زيادة نسبـة الجلـوكوز في الدم وتركيز الدهون الثلاثية في النسيج الدهني



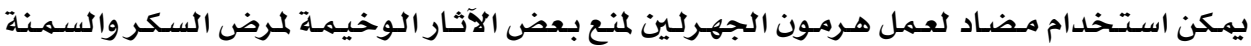
وذلك بالأخص للأشخاص الذين يعانون من زيادة مستوى الجهرلين بالدم أو زيادة استجابة أنسجة الجسهم لهذا الهرمون.

وكذلك يهكن استخدا مـه بجرعة مناسبـة لعلاج بعض الأمـراض مثل فقد الشهية العصابى.

MANSOURA MEDICAL JOURNAL 